\title{
Entre lembranças e silêncios: reflexões sobre uma autobiografia feminina
}

\author{
Between recollections and silences: \\ reflections about a feminine autobiography \\ Cláudia Maria de Farias
}

\section{Considerações iniciais}

A participação de mulheres nos Jogos Pan-Americanos de 2007, realizados no Rio de Janeiro, foi de aproximadamente 310 atletas. Em 2004, nas Olimpíadas de Atenas, 122 brasileiras estiveram presentes - praticamente a metade dos 247 atletas da delegação olímpica. Porém, se hoje a participação feminina nas competições esportivas é incontestável, nem sempre foi assim. Em 1912, o barão Pierre de Coubertin - idealizador das Olimpíadas da Era Moderna e então presidente do Comitê Olímpico Internacional - defendia, de forma contundente, a exclusão das mulheres da competição ao frisar que "os jogos olímpicos são a exal-

Cláudia Maria de Farias é doutoranda no Programa de Pós-Graduação em História da UFF e bolsista do CNPq (cdfarias@ig.com.br).

Artigo recebido em 24 de novembro de 2008 e aprovado para publicação em 14 de janeiro de 2009. Nota da autora: Agradeço à professora Rachel Soheit pela leitura e as sugestões.

Estudos Históricos, Rio de Janeiro, vol. 22, nº 43, janeiro-junho de 2009, p. 238-257. 
tação solene e periódica do esporte masculino". Posteriormente, em seu tratado Princípios filosóficos do olimpismo moderno, de 1936, ele afirmava:

O verdadeiro herói olímpico é, a meu ver, o homem adulto. (...) Não aprovo a participação das mulheres em competições públicas. Isto não significa que elas devam se abster de praticar esportes, mas não devem dar espetáculo. Nos jogos olímpicos seu papel deveria ser sobretudo, como nos antigos torneios, o de coroar os vencedores. (Coubertin apud Cardoso, 2000: 30)

Não obstante as manifestações contrárias do barão e as interdições impostas pelo Comitê Olímpico Internacional, que lhes negava inclusive o direito de subir ao pódio, as mulheres lentamente superaram preconceitos e protestos violentos ao longo do século XX. Toleradas em alguns esportes até 1912, como o tênis, patinação e tiro com arco, elas foram conquistando cada vez mais espaços, num território destinado às honras e virtudes masculinas. Assim, pressionado pelo avanço do movimento feminista no campo esportivo, Pierre de Coubertin renunciou à presidência do COI, em 1925. Três anos depois, nos Jogos de Amsterdã, as provas de atletismo - consideradas impróprias para o "sexo frágil" - foram incluídas no programa olímpico, para desespero do barão. A partir dos anos 1920, como reflexo das lutas femininas travadas no cenário esportivo internacional, a projeção das mulheres brasileiras nos esportes se realizou nas modalidades que ressaltavam a distinção, a graça, a beleza e a leveza "natural" dos movimentos femininos: ginástica, natação, tênis, voleibol, equitação, esgrima.

Através desta associação, em que se distinguiam as atividades esportivas consideradas mais adequadas à identidade feminina, o discurso médico-eugênico transformava o corpo em objeto de discussão e análise, construindo paralelamente representações de feminilidade e masculinidade que apontavam para uma moralização dos corpos e uma diferenciação "natural" entre os sexos, as classes e as raças.

Na revista Sports, Fernando Azevedo assim manifestava suas concepções sobre a educação física e os esportes para as mulheres:

A educação física para moças deve ser, pois, higiênica e estética, e nunca atlética, visar sobretudo o desenvolvimento da parte inferior do corpo, dar a graça e a destreza dos movimentos, procurando antes a ligeireza do que a força. (...) Os exercícios para a mulher (porque sua estrutura é mais fraca e delicada do que a do homem) devem ser menos 
enérgicos e ter menos duração. É contra-indicado todo e qualquer exercício que exija dispên dio muscular intenso e prolongado. (Azevedo apud Schpun, 1999: 34)

No raciocínio de Fernando Azevedo, às mulheres restava apenas se exercitarem para a manutenção da saúde, da elegância e beleza. Desviadas dos instintos ligados à competitividade e agressividade, suas preocupações deveriam ser com os exercícios delicados, harmoniosos e contemplativos - considerados mais adequados à morfologia feminina -, como a natação, a dança e os passeios ao ar livre. Excluídas das competições esportivas públicas - lugar exclusivo da virilidade e ambição masculinas -, elas deveriam se dedicar apenas ao espaço doméstico, nunca se descuidando da maternidade, sua principal vocação e tarefa.

Apesar do moralismo e do machismo predominantes na época, Maria Lenk iniciou a natação feminina competitiva no país ao conquistar o primeiro lugar na prova interestadual entre nadadoras do Rio de Janeiro e São Paulo, realizada na Enseada de Botafogo, em 1931. Assim, ela seguia os passos anteriormente dados por Blanche Pironnet, Jandira Barroso, Violeta Coelho Neto, Anésia Coelho e Alice Possolo entre o final da Primeira Guerra Mundial e o início da década de 1920. Em 1932, aos 17 anos, Maria Lenk ainda protagonizou uma façanha inédita: sem a presença do pai - fato incomum na época -, ela viajou a bordo do navio cargueiro Itaquicê, durante quase um mês, entre 66 atletas homens da delegação brasileira, para ser a primeira mulher sul-americana a competir em Olimpíadas. Educada desde cedo pelo pai - um imigrante alemão - nos princípios da ginástica, de quem recebeu também os primeiros ensinamentos na natação, ela ainda venceu a Travessia de São Paulo a Nado, no rio Tietê, de 1932 a 1935, sempre despertando a curiosidade e a estranheza do público espectador, embora a natação fosse vista como um esporte distinto, mais apropriado ao sexo feminino. Após participar também da Olimpíada de 1936, em Londres, e quebrar dois recordes mundiais de natação, ela encerrou a carreira esportiva em 1942, dedicando-se à cátedra de natação na Escola Nacional de Educação Física e Desportos, criada em 1939 por Getúlio Vargas. Posteriormente, no final dos anos 1960, foi a primeira mulher a ser nomeada diretora dessa escola e a integrar o Conselho Nacional de Desportos (CND), onde lutou pelo fim das restrições à prática esportiva feminina, impostas pelo autoritarismo do Estado Novo, através de Decreto Lei n. 3199, de 14 de abril de 1941, e reeditadas em 1965 pela ditadura militar, com a inclusão de novas modalidades esportivas. ${ }^{1}$

Decorridos 50 anos da experiência vivida nos Jogos Olímpicos de Los Angeles, em 1932, Maria Lenk decidiu escrever sua autobiografia, Braçadas e abraços, narrando sua trajetória na natação brasileira de 1930 a 1942. Consideran- 
do-se uma "testemunha ocular da história", por ter vivenciado como amadora os primórdios da natação feminina no país, sua narrativa será entendida aqui como expressão constitutiva da identidade de sua autora e de seu texto, criadas, simultaneamente, através dessa modalidade de "produção do eu" (Gomes, 2004: 16). Portanto, demonstrarei como o recurso da "escrita de si" permitiu, em última instância, que Maria Lenk, ao rememorar um determinado período da sua vida pública, estabelecesse uma comunicação consigo mesma e com os outros, construindo discursivamente um ponto de vista sobre si e sobre os acontecimentos vividos que contribuiu para seu autoconhecimento, sua autoexplicação e autojustificação, conforme nos sugere Oberti (2006: 48), num esforço contínuo de elaborar, até mesmo de forma terapêutica, sua reconciliação com o passado, sua redenção no presente e projetar também sua visão de futuro para o esporte brasileiro. ${ }^{2}$ Ao eleger parte de seu relato autobiográfico como objeto de investigação deste trabalho, buscarei, então, identificar as condições de sua produção, o quadro social de sua constituição, bem como o interlocutor imaginário ao qual o relato se dirige e o tipo de relação que o narrador estabelece com ele (de sedução ou de desafio), segundo sugere Pereira (2000: 124), sem desconsiderar a estruturação da sua memória, com suas frustrações, seus ressentimentos e silêncios, e as estratégias de representação articuladas na tentativa de produzir um sentido exemplar para sua trajetória de vida, cristalizando uma determinada imagem de si.

Por razões metodológicas, somada a esta fonte, utilizarei o periódico Fornal dos Sports, com vistas a elaborar um exame crítico do testemunho de Maria Lenk, referente às suas lembranças das Olimpíadas de 1932, pois, de acordo com Sarlo (2005: 57), "no hay equivalencia entre el derecho de recordar y la afirmación de una verdad del recuerdo; tampouco el deber de memória obliga a aceptar esa equivalencia" e, portanto, não devemos desprezar as fontes escritas (quando existirem), produzidas no transcurso dos fatos e portadoras do espírito da época. Com a investigação em torno dos problemas, das dificuldades e dos escândalos vivenciados pela delegação brasileira nas Olimpíadas de 1932, retratados no fornal dos Sports, pretendo revelar as lacunas, os “ditos" e os "não-ditos" do relato de Maria Lenk, no intuito de melhor compreender a lógica presente na construção da sua memória sobre esse evento. Dessa forma, objetivo tornar explícitas algumas questões e problemas presentes nos relatos de histórias de vida: a ilusão biográfica, o esquecimento e o anacronismo.

A armadilha representada pela "ilusão biográfica" consiste em não deslindarmos as omissões ou a escassez de episódios dolorosos e controversos no relato, que poderiam trazer danos à imagem do narrador, impedindo a construção de uma personalidade coerente e estável, cuja trajetória fosse linear, com sentido 
e direção estabelecidos previamente. ${ }^{3} \mathrm{O}$ segundo problema, referente ao anacronismo, sugere que o historiador reconheça as diversas tessituras temporais superpostas na trama discursiva da memória, espaço ficcionalizado por procedimentos narrativos, onde o passado é relembrado sempre a partir das imposições do presente conjugadas, de forma cambiante, às expectativas de futuro, condição da "impureza do testemunho", de acordo com Sarlo (2005: 80), mas também da sua singularidade, dinâmica e complexidade. Neste sentido, ao trabalharmos com a perspectiva memorialística, cabe nos indagar como o sujeito se recorda das suas experiências,

lo que olvida, lo que calla intencionalmente, lo que modifica, lo que inventa, (...) lo que sua ideas actuales le indican que debe ser enfatizado en función de una acción política o moral en el presente, lo que utiliza como dispositivo retórico para argumentar, para atacar o defenderse, lo que conoce por experiencia y lo conoce por los medios, que se confunde, despúes de un tiempo, con su experiencia etc. etc. (Sarlo, 2005: 79)

A despeito dos perigos que cercam este campo do conhecimento, especialmente no tocante à pretensão de transparência do testemunho e de unidade do sujeito que narra suas experiências, a abordagem biográfica pode ser de suma importância para a apreensão dos percursos tanto das mulheres "excepcionais" quanto das mulheres "comuns", evidenciando, no caso em questão, as dificuldades e os obstáculos enfrentados para penetrarem e permanecerem no campo esportivo - espaço social destinado à celebração da virilidade masculina -, bem como as formas de resistência e as estratégias articuladas na busca pela afirmação dos seus direitos e das suas múltiplas identidades, haja vista que em nenhum momento elas devem ser entendidas como uma categoria homogênea e, portanto, outros componentes de diferenciação social devem ser agregados à perspectiva de gênero, como geração, classe e raça/etnia, segundo destaca Soihet (1997: 277).

Para além de evidenciar esses fatores, o trabalho pretende realçar a dimensão coletiva da memória individual ao iluminar "un contexto social, la pertencia a un grupo, a una clase, a un gênero", na medida em que o relato autobiográfico é uma construção intersubjetiva, “compartida (...) que no se puede realizar sin el auxilio de outros, tanto aquellos traídos al relato en el proceso de invocación, como aquellos con los que las narraciones propias se confrontan o se confirman" (Oberti, 2006: 50). 


\section{A escrita autobiográfica: experiências e horizontes de um lugar de memória}

Antes de iniciar o relato das suas experiências propriamente dito, Maria Lenk decidiu informar o leitor sobre suas intenções e sobre o modo como apresentaria sua autobiografia Braçadas e abraços, numa espécie de preâmbulo à obra, que denominou "Desde há 50 anos". Tais ponderações assinalam, de antemão, a estrutura narrativa adotada pela autora para apresentar "um curto espaço de tempo" de competições de natação, entre os anos de 1930 e 1942, e celebrar um "marco na história desportiva continental", protagonizado por ela e representado pelo jubileu em que pela primeira vez uma mulher sul-americana participou dos Jogos Olímpicos, em agosto de 1932. Neste sentido, a narradora situa sua experiência passada num horizonte de temporalidades delineado, simultaneamente, por suas motivações no presente e expectativas de futuro, haja vista que na segunda parte da obra, denominada "Por amor aos desportos", ela apresenta várias considerações para que o Brasil siga novos rumos no esporte, "caso deseje, de fato, competir em igualdade de condições com as demais nações nos encontros internacionais" (Lenk, 1982: 177, grifos da autora).

Com efeito, ao articular uma multiplicidade de tempos concomitantemente, a ex-nadadora procurava "cotejar a época em que competia com a atual" para chamar a atenção da "nova leva de campeões, representantes de uma geração moldada pelo progresso tecnológico, mais realista e livre de tabus" e enfatizar as circunstâncias desfavoráveis nas quais se realizaram suas conquistas e seus fracassos esportivos, marcadas pelo preconceito de gênero e pelas dificuldades da prática do esporte amador. Através dessa estratégia, ela buscava sensibilizar e seduzir os "jovens leitores", despertando a complacência "pelo que de limitado e até mesmo grotesco se apresenta para eles", bem como a "melancolia dos leitores seus contemporâneos", uma vez que hoje, diferentemente das condições experimentadas pela autora e pelos esportistas da sua geração, ${ }^{4}$ uma nova safra de campeões, "mais capaz de grandes proezas, quando devidamente assistida pela geração que a precedeu e que hoje ocupa os cargos de direção, poderá alcançar o que em tempos idos representava apenas um sonho impossível" (Lenk, 1982: 11).

Neste sentido, a partir das pistas dadas por Ligia Maria Pereira acerca dos interlocutores imaginários com os quais o narrador do relato autobiográfico dialoga e o tipo de relação que deseja estabelecer com eles, é possível dizer que Maria Lenk desejava transmitir suas experiências a um público constituído por dois grupos diferenciados. O primeiro grupo, formado por ex-atletas e dirigentes esportivos - seus contemporâneos que, constantemente invocados ao longo do 
relato, poderiam se identificar com ela e acionar, "por tabela", 5 as suas próprias recordações -, e o segundo, composto de atletas das novas gerações, nos quais desejava provocar reações de empatia, admiração e respeito pela sua trajetória singular, pontuada por conquistas, dissabores, lutas e superações. Dessa maneira, ela situava sua experiência em distintos horizontes temporais e estabelecia uma escuta entre uma ampla "comunidade afetiva", ${ }^{6}$ formada por desportistas de diferentes gerações, na medida em que, para além de acionar lembranças do passado de vida comum no primeiro grupo, promovia, indiretamente, identificações nos atletas mais novos, mesmo naqueles com pouca experiência esportiva, criando sentimentos coletivos de pertencimento, autoconfiança e valorização, principalmente se considerarmos o impacto que as histórias de abnegação, coragem, superação e resignação produzem na comunidade esportiva. Conforme destaca Jelin (2001: 33), "la memoria es una representación del pasado construida como conocimiento cultural compartido por generaciones sucesivas y por diversos/as otros/as. En verdad, se trata de pensar la experiencia o la memoria en su dimensión intersubjetiva, social".

Outro recurso utilizado por Maria Lenk no preâmbulo da sua autobiografia refere-se à maneira como decidiu se apresentar ao leitor. Vejamos:

(...) devo assinalar que eu própria, condicionada à época atual, "atualizada", como dizem os jovens quando desejam elogiar os “coroas", vejo-me tão distante daquela fase de minha vida que quase não me identifico comigo mesma. Por isso, achei por bem tratar-me e apresentar-me como se outra pessoa fosse e, talvez seja, segundo os conceitos científicos que professam uma renovação celular contínua no ser humano. Este proceder não retira, mesmo assim, perdoem-me meus caros leitores a falta de modéstia já que assinala, ainda que de forma seletiva, as performances por mim alcançadas, causando a repetição constante do meu nome - MARIA LENK - que é uma simplificação do que consta no registro de nascimento, MARIA EMMA HULDA LENK, ao qual adicionei, mais tarde, o de ZIGLER, por força do casamento. (Lenk, 1982: 11, grifos da autora)

Ao frisar as mudanças do seu próprio nome e as mutações biológicas de todo ser humano ao longo da vida, Maria Lenk afirmava já não se identificar consigo mesma, criando uma identidade narrativa que, através do relato na terceira pessoa, buscava um afastamento crítico para melhor refletir ao leitor o orgulho pelos feitos atingidos no passado - percebidos como significativos de um período excepcional da sua vida - e realçar seu compromisso com a verdade dos 
fatos na atualidade. A dimensão dialética da "identidade narrativa", ${ }^{7}$ construída no relato sem a plena presença do sujeito, permite, então, que Maria Lenk, "como se outra pessoa fosse", tome distância das suas experiências e se apresente, simultaneamente, por meio da oposição e conciliação que estabelece na narrativa entre autora, narradora e personagem. Para além do fio condutor presente em toda história de vida, conforme destaca Pollak (1989: 15), através deste recurso a ex-atleta construía uma reflexão a posteriori sobre sua trajetória, expondo-se de forma mutável e compreensível para si e para os interlocutores com os quais desejava dialogar e garantir uma identificação. De acordo com Oberti (2006: 49),

la noción de identidad narrativa logra salvarla del sin sentido de la sucesión incoherente de acontecimientos, inaprehensibles durante el fluir de la vida; por el outro lado, y en un solo y mismo acto, la dinámica narrativa impide a la identidad convertirse en una sustancia inmutable e inaccesible al devenir.

No entanto, a busca de um efeito de verdade não se faz sem que Maria Lenk também recorra a outras vozes do passado, sempre referenciadas em caixa alta no relato e materializadas através

principalmente de recortes de jornais e revistas carinhosamente guardados por minha saudosa mãe, ROSA LENK, que os colecionou, em ordem, encadernando-os e, agora, enfeitando o espaço respeitável em minha biblioteca. Outra fonte de informações que prezo, com ternura filial, é o diário do meu amado pai, PAUL LENK (...), completando os registros de ocorrências com o que me vinha à memória, muitas vezes reforçada pela troca do "você se lembra" em gostosos bate-papos com desportistas meus contemporâneos. (Lenk, 1982: 11)

A "vontade de guardar"8 da família Lenk, representada pelo acúmulo de registros organizados, arquivados e, posteriormente, doados por Maria Lenk à Biblioteca de Pós-Graduação em Educação Física da Universidade Gama Filho ${ }^{9}$ - instituição onde trabalhou como professora no antigo Colégio Piedade-, significou a possibilidade da reconstrução exitosa de sua vida pública, num permanente trabalho de "enquadramento de memória" 10 realizado através da seleção, celebração e eternização de determinados feitos e fatos colecionados que, alçados à categoria de "prova" da veracidade do seu relato, alimentaram e forjaram, de 
forma subjetiva e intencional, a construção de uma imagem positiva de si, consolidando seu reconhecimento e legado pessoal pelas gerações seguintes. Dessa forma, desfrutando de uma posição de autoridade ao atuar como "guardiã da memória" 11 familiar e do grupo ao qual pertenceu, a doação do arquivo de Maria Lenk nos informa sobre o sentido autobiográfico desta ação e a lógica da acumulação em arquivos privados/pessoais, pois

a produção de uma imagem é fruto tanto do que se exibe quanto do que se esconde. Nesta operação participam tanto o círculo familiar do arquivador quanto as instituições de memória. Só doa arquivo quem supõe que seus documentos vão configurar para a história o que o titular enquanto ator foi para sua época. É difícil imaginar o gesto de doação sem o espírito de notabilização. Do ponto de vista da memória não se exibe o que não se releva; não se expõe, conscientemente, o que não seja rentabilizável como preservação de imagem. O gesto de doar neste caso está sendo tomado como ato deliberado de vontade. (...) Doar uma coleção cerca-se por certo de indagações, receios, pressupõe relações de confiabilidade que apontam um consenso sobre o caráter relevante dos papéis doados. (Vianna, Lissovsky e Moraes de Sá, 1986: 69)

Por fim, a autora comunica ao leitor que a metodologia da obra "foge à sequência cronológica exata", demonstrando, mais uma vez, como sua narrativa é atravessada por diversas texturas temporais que se cruzam e interpenetram constantemente. A despeito das descontinuidades que marcam o relato, Maria Lenk apresenta alguns "capítulos à parte", representados pelos Jogos Olímpicos de 1932 e 36, "dos quais teve a ventura de participar", e os Jogos de 1940 "NÃO REALIZADOS" (grifos da autora), em função da Segunda Guerra Mundial. Este horizonte temporal constitui, na verdade, a trama central do relato; o fio condutor da narrativa estabelecido para a sua biografia, período representativo do ápice e encerramento da sua trajetória esportiva, "certamente relevante nos esforços que despendi para a obtenção dos meus objetivos atléticos" (Lenk, 1982: 13). Com efeito, ao tratar esse período como marco inaugural e final de sua carreira esportiva, a ex-nadadora enfatizaria os desejos, as frustrações e os ressentimentos que seriam os impulsionadores dos seus comportamentos e atitudes no passado e dariam o tom da sua memória no presente, numa nítida catarse das suas antigas angústias e do seu ódio recalcado pelas experiências humilhantes e mal-sucedidas em 1932 e 1936 e pelo "não vivido" em 1940, já que após bater dois recordes mundiais de natação em 1939, encontrava-se em plena condição de conseguir uma medalha olímpica, reabilitando-se dos insucessos anteriores. 
Através dessa trama discursiva, portanto, ela construía um destino linear para si mesma, dotado de justificativa, legitimidade e coerência internas. Neste sentido, é preciso considerar como os (res)sentimentos de raiva, indignação e orgulho ferido possibilitaram a Maria Lenk elaborar um testemunho crível no presente e, por outro lado, construir laços de identidade, solidariedade, coesão grupal e um projeto de vida no passado. Conforme destaca Ansart (2004: 22), "o ódio recalcado e depois manifestado cria uma solidariedade afetiva que, extrapolando as rivalidades internas, permite a reconstituição de uma coesão, de uma forte identificação de cada um com o seu grupo".

Em face do exposto, a autobiografia Braçadas e abraços deve ser considerada um "lugar de memória" (cf. Nora, 1993: 7-28), individual e coletiva, uma vez que permitiu o ordenamento e a elaboração da trajetória, das experiências e expectativas de Maria Lenk, cujos significados e sentidos foram produzidos, simultaneamente, pela autora e pela narrativa construída em permanente diálogo e interação com outros, mas também através das ambiguidades, dos silêncios e esquecimentos da sua memória, conforme veremos adiante.

\section{Recordaçães dos Jogos Olímpicos de 1932: os “ditos" e "não ditos" de Maria Lenk}

O capítulo inicial da autobiografia Braçadas e abraços é denominado "A alvorada da natação feminina no Brasil”. Nele, Maria Lenk relembra e situa o surgimento da natação competitiva feminina no Brasil nos primeiros anos da década de 1930, mais precisamente em 1931, ano de realização da primeira competição interestadual de natação entre mulheres de São Paulo e do Rio de Janeiro. No evento esportivo, ela e Marina Cruz representaram o estado de São Paulo, obtendo o $1^{\circ}$ e o $2^{\circ}$ lugares, respectivamente. A nadadora carioca Olívia Calvert ficou em $3^{\circ}$ lugar. Vale ressaltar, no entanto, que a lembrança desse acontecimento é inserida após Maria Lenk mencionar a "sensacional exibição" de Violeta Coelho Neto, feita no tanque natatório da Urca, no Rio de Janeiro, "por ocasião dos festejos do centenário da Independência do Brasil, em 1922", e a Travessia da Guanabara, realizada pelas "intrépidas senhoritas" Anésia Coelho e Alice Possalo em 1925.

Além desses episódios, a autora cita ainda as experiências, na mesma época, em São Paulo, de um "pequeno grupo de moças da colônia alemã, que rompeu as maiores barreiras antepostas à mulher no desporto pelos costumes e preconceitos locais, ao se apresentar em público para nadar, envoltas em prodigiosos costumes de banho, abundantes em dobras e babados" (Lenk, 1982: 17). 
Tais referências, embora fossem utilizadas para enfatizar a luta da mulher brasileira pela sua emancipação naquele contexto, revelavam uma "consciência de gênero" (cf. Perrot, 2005: 279) ambígua de Maria Lenk. Para além de realçar o pioneirismo de algumas nadadoras e o lugar ocupado por ela como primeira mulher sul-americana a participar de uma olimpíada, frisavam a "fama da natação de dispensar a força muscular, não prejudicando as virtudes femininas de graciosa fragilidade imposta pelo machismo dominador", motivo pelo qual as nadadoras enfrentariam "menores resistências", principalmente aquelas da colônia alemã, tradicionalmente adeptas da cultura física.

Neste sentido, Maria Lenk - também filha de imigrantes alemães - minimizou os preconceitos e obstáculos enfrentados por ela e outras mulheres para ingressar e permanecer na natação competitiva brasileira, já que tal iniciativa significava romper as recomendações médicas de moderação para a prática esportiva feminina na busca por projeção e visibilidade no espaço público. Mesmo reconhecendo que a natação era vista como um esporte feminino, a própria Maria Lenk afirmou, de forma contraditória, numa entrevista concedida a Mourão (1998: 145), que "no momento em que a menina se tornava moça e começava a namorar, a primeira coisa que o namorado fazia era proibir ela de nadar".

A ambiguidade manifestada por Maria Lenk, em torno do preconceito de gênero, ${ }^{12}$ aparece, de forma mais clara, no início do capítulo seguinte, "X Jogos Olímpicos em Los Angeles - 1932". Ao selecionar e reproduzir algumas palavras pronunciadas por Pierre de Coubertin na abertura dos primeiros Jogos Olímpicos da Era Moderna, realizados em 1896, em Atenas, Lenk não escondia sua admiração pelo "humanista e arqueólogo francês", idealizador e responsável pelo renascimento das Olimpíadas, que insistia na democracia e no internacionalismo pacífico entre as nações, inspirado pelo espírito desportivo de igualdade, cavalheirismo e respeito ao adversário. Contudo, em seu relato, ela "esquecia" de lembrar a exclusão das mulheres das competições olímpicas, exaustivamente defendida por Pierre de Coubertin ao longo de seu comando no Comitê Olímpico Internacional e fortemente combatida através da pressão da Federação Internacional de Natação (FINA), exigindo as provas femininas de natação no programa das Olimpíadas, fato ocorrido apenas nos Jogos de Estocolmo, realizados em 1912.

Esses esquecimentos se revelariam, de forma mais contundente, na parte da sua autobiografia dedicada às recordações da viagem rumo às Olimpíadas de Los Angeles, em 1932. A descrição da viagem que realizou, entre 66 atletas homens e mais os dirigentes da delegação olímpica brasileira, assume um caráter altamente idílico e romântico, repleta de encantos e passagens onde a natureza sempre se fazia presente: 
Podia-se observar o alegre brincar dos botos em torno da proa do navio ou, por vezes, a ferocidade de um tubarão martelo, que acompanhava o navio à espera dos restos da carne, jogados ao mar. À noite, o espetáculo fulgurante de uma enorme lua cheia (aparentemente maior nas proximidades do Equador) que prateava o mar, revezava-se com outro, não menos encantador, que fora a fosforescência das ondas pelas ardentias, transformando-as em tiras de luminosidade indo ao encontro do casco do navio (Lenk, 1982: 30).

Para completar o cenário exuberante, Maria Lenk também lembrava a felicidade e despreocupação dos jovens atletas brasileiros na viagem:

O auge da alegria alcançou-se por ocasião do "batismo" dos estreantes em atravessar o Equador (...). Montou-se uma "piscina" de caixotes revestidos com lona (...). Ninguém conseguiu escapar do banho que, afinal, foi aceito com bom humor até pelos sisudos "cartolas". A existência da linha do Equador, motivo de todo esse reboliço, deveria ser comprovada. Não tiveram dúvidas nosso peraltas, que faziam com que todos olhassem por uma luneta que tornara realmente visível uma nítida linha sobre as ondas (não suspeitavam os incautos que na lente havia sido colocado um fio de cabelo). Aos mais ingênuos parecia mesmo que o navio dera um forte solavanco sobre tão importante fenômeno marítimo. (Lenk, 1982: 50)

O relato pormenorizado do trajeto reflete, conforme destaca Sarlo (2005: 68) "un modo realista-romántico de fortalecimiento de la credibilidad del narrador y de la veracidad de su narración", ou seja, o trabalho de "enquadramento da memória" realizado por Maria Lenk para representar, de forma idealizada e inocente, certos episódios dessa experiência, na verdade, pontuada por vários dramas, polêmicas e efetivada num navio cargueiro que, certamente, não apresentava condições adequadas de acomodação para tantos passageiros, ainda que os conduzisse. Além disso, muito provavelmente, a viagem foi marcada pelas expectativas e preocupações dos atletas brasileiros, pois, na falta de recursos em espécie, ficou condicionada à venda de 55.000 sacas de café - arrancadas da fogueira por Renato Pacheco, então presidente da Confederação Brasileira de Desportos (CBD) - em portos estrangeiros para despesas de custeio da viagem, uma vez que não existia ainda apoio financeiro do Governo Federal, nem tampouco do Comitê Olímpico Brasileiro. 
Os percalços de tão penosa viagem, minimizados no relato, ainda ganhariam contornos mais dramáticos. O primeiro transtorno ocorreu por ocasião da entrada do navio no canal de Panamá, quando teria que se pagar um alto pedágio para a travessia. Na tentativa de enganar os funcionários encarregados da cobrança e se livrar do pedágio, o governo brasileiro disfarçou o cargueiro de navio de guerra antes de sua partida, colocando dois canhões na proa e uniformizando devidamente a tripulação. Todavia, a estratégia revelou-se infrutífera quando os inspetores de pedágio detectaram a inscrição "Delegação do Brasil a X Olimpíada" no casco do navio e os porões abarrotados de café, que o caracterizariam como navio mercante. Depois de muita diplomacia e negociação, se conseguiu que o pedágio fosse pago na volta com o dinheiro da venda do café.

Após atracarem no porto de Los Angeles, a delegação brasileira, sem ter conseguido vender o "ouro negro" na ilha inglesa de Trinidad, se deparou com outro grande problema: era preciso pagar um dólar por pessoa no desembarque e o chefe da delegação brasileira, cujo nome, estranhamente, é omitido por Maria Lenk, só dispunha de 24 dólares no total. Depois de muita discussão, os dirigentes decidiram que somente os "atletas considerados de maiores possibilidades no desempenho de suas respectivas provas desembarcariam". Os demais seguiriam viagem até São Francisco, na esperança de vender o café e voltar a tempo para a competição. Esta é a única passagem do relato onde a autora evidencia a mistura de sentimentos de tristeza e alegria que predominou entre a delegação brasileira na época, já que muitos atletas foram impedidos de desembarcar e desfalcaram a equipe no desfile de abertura do evento.

Deve-se ressaltar ainda o destaque dado por Maria Lenk à façanha e ao heroísmo de Adalberto Cardoso, atleta brasileiro que, impedido de desembarcar do navio em Los Angeles, foi ovacionado pelo público ao correr descalço os 10 mil metros e adentrar o estádio poucos instantes antes do início da prova, após "acidentada viagem, sem um centavo no bolso, dependente de carona e até da generosidade alheia para comer". Quanto à autora e personagem desta história, parece que, depois de desembarcar e ficar hospedada em hotel destinado exclusivamente às concorrentes femininas, "participou em todas as provas de natação nos 3 estilos então constantes do programa, saindo-se melhor nos $200 \mathrm{~m}$ nado de peito, onde registrou o oitavo melhor tempo entre todas as concorrentes" (Lenk, 1982: 31).

No final do capítulo, ao relatar brevemente a chegada da delegação brasileira no Rio de Janeiro, em meio à Revolução Constitucionalista de 32 em São Paulo, a ex-atleta se entrega à reflexão e se pergunta se valeu a pena, não sem antes esboçar a ocorrência de "críticas de toda ordem, comum a qualquer empreendimento de êxito duvidoso". No entanto, a ocupação posterior de alguns cargos administrativos de projeção no desporto nacional e internacional por alguns 
atletas da geração de 1932 faz com que prevaleça no seu relato um balanço positivo das vivências experimentadas no passado, fundamentais para a formação moral de uma geração movida por um idealismo patriótico: "Pode-se dizer que, de uma forma ou de outra, todos os jovens brasileiros que lá estiveram tomaram conhecimento da importância do desporto como elemento educacional por excelência, dentro dos elevados conceitos do 'mens sana in corpore sano" (Lenk, 1982: 37). Por fim, Maria Lenk enfatizava, principalmente, o valor dessa experiência na consolidação de seu sentimento patriótico e na construção obstinada da sua própria personalidade e trajetória esportiva ao afirmar:

No que diz respeito a MARIA LENK, foram também os Jogos Olímpicos de Los Angeles que a conscientizaram para a prática do desporto em sua forma séria e fundamental. Instigou-a daí por diante, não só o ideal olímpico, mas, sobretudo, seu patriotismo ferido por tantas desventuras, para o que desejava ardentemente uma reabilitação. De então por diante haveria de dedicar-se a uma luta sem tréguas, vencendo todos os obstáculos, treinando intensamente, até que o mundo desportivo tomasse conhecimento deste país que tanto ama e que um generoso destino lhe havia reservado como sua Pátria. (Lenk, 1982: 38)

Paradoxalmente, o (res)sentimento de amor próprio ferido surgido em 1932 ainda daria o tom da sua memória mais adiante, ocupando lugar central também no que concerne às suas recordações das Olimpíadas de 1936, realizadas em Berlim, quando viajou com mais cinco mulheres, quatro nadadoras e uma esgrimista, sendo a melhor colocação a da nadadora Piedade Coutinho $\left(5^{\circ}\right.$ lugar na prova de $400 \mathrm{~m}$ livre). Apesar de relatar suas "excelentes performances durante os torneios de preparação olímpica, estabelecendo um recorde mundial nos 100 $\mathrm{m}$ nado de peito", sendo inclusive a única mulher nadadora a empregar o difícil nado "borboleta" nos Jogos de 1936, realizado apenas por poucos homens na época, a experiência é sentida como mais uma "grande decepção", não permitindo que a atleta reconhecesse e valorizasse sua singularidade e, principalmente, se vingasse da experiência de 1932. Ressentimento acirrado ainda mais pelo cancelamento dos jogos de 1940. A revanche tão sonhada só ocorreu em 1942, por ocasião de um torneio de "boa vizinhança", onde Maria Lenk venceu todas as disputas realizadas, superou 12 vezes os recordes americanos e encerrou sua carreira esportiva. Vejamos:

Apesar de não ter concretizado seu maior sonho, o de vencer a medalha de ouro nas Olimpíadas de 40, pois a guerra riscou-os 
do calendário, sentiu-se compensada. Nos EUA, mais precisamente em Los Angeles, em 1932, havia sofrido as agruras da derrota. Agora, dez anos depois, reabilitou-se, conseguiu a revanche para si e a natação brasileira. Podia, agora, afastar-se tranquila das competições. Havia cumprido sua missão. (Lenk, 1982: 132)

Seguindo as pistas dadas por Pollak (1989:8) no tocante às zonas de luz, sombra, silêncios e "não-ditos" que marcam a fronteira entre o dizível e o indizível da memória, intrigou-me o fato de Maria Lenk conservar lembranças tão contraditórias dessas experiências esportivas, às vezes idealizadas e ufanistas, outras vezes visivelmente ressentidas e rancorosas a ponto de mencionar, em várias passagens, as decepções, diminuições e humilhações sofridas, apesar da notoriedade adquirida no campo esportivo por ter sido a primeira mulher latino-americana a participar de uma Olimpíada.

Instigada por isso e movida pelas sugestões de Beatriz Sarlo, sobre a necessidade de se pesquisar outras fontes documentais para elaborarmos um exame crítico dos testemunhos, decidi investigar a repercussão da participação brasileira nas Olimpíadas de 1932 no fornal dos Sports. Foi então que descobri e compreendi a razão dos ressentimentos de Maria Lenk e, por conseguinte, a lógica predominante na construção da sua memória. Em uma "declaração causticante", estampada na capa do jornal em 20 de setembro de 1932, ela afirmou que "a mulher no Itaquicê tinha que andar armada para defender sua integridade física e moral". ${ }^{13}$ A afirmação bombástica deu origem a uma série de reportagens investigativas do fornal dos Sports que denunciava as polêmicas e os escândalos ocorridos em torno desse evento esportivo. As matérias publicadas no jornal, entre os dias 20 e 22 de setembro de 1932, revelavam o total descaso do chefe da delegação brasileira, Capitão Orlando Silva, com seus atletas, muitos dos quais passaram fome e outras privações, como por exemplo a equipe do 4 x $400 \mathrm{~m}$ do atletismo masculino, que se ausentou da prova porque não "estava em condições físicas aconselháveis por falta de alimentação", conforme entrevista de Domingos Puglisi, atleta da equipe. ${ }^{14}$ No entanto, o tesoureiro da delegação olímpica "trouxe um saldo de 2 mil dólares" 15 e o Capitão Orlando "pôde comprar nada menos que 11 aparelhos de rádio". ${ }^{16}$ Além de tudo isso, a entrevista de Pandiá Pires, jornalista que acompanhou a delegação olímpica em Los Angeles, destacava ainda:

Maria Lenk, a futurosa nadadora patrícia, entregue aos cuidados do Capitão Orlando Silva, ficou abandonada durante 7 dias, sem a menor assistência dos que dirigiam a delegação, sobretudo do Capitão Orlando Silva. Casualmente, ela encontrou um dos chefes na rua, 
reclamou dele e, então, fizeram o "sacrifício" de tomar as devidas providências. ${ }^{17}$

Muito possivelmente, essas foram as causas que levaram Maria Lenk a suprimir da sua autobiografia o nome do chefe da delegação brasileira nas Olimpíadas de 1932, Orlando Silva. Não mencioná-lo significou a vontade de Maria Lenk de silenciar sobre episódios dolorosos de abandono e, talvez, até de assédio ou violência sexual que, se viessem à tona, poderiam expô-la a mal-entendidos, manchando sua reputação e trajetória. Afinal, de acordo com Perrot (2005: 295), não podemos esquecer a suspeita que pesa sobre as viagens e os deslocamentos das mulheres, sobretudo das mulheres sós. Ao mesmo tempo, seu silêncio representou a alternativa mais eficaz para sobreviver aos traumas e sofrimentos passados, quem sabe, os verdadeiros motivos das diminuições e humilhações vivenciadas tão solitariamente na competição, nunca esquecidas e que tanto marcariam sua carreira esportiva e seu testemunho no presente.

\section{Palavras finais}

Ao escrever sobre a história das mulheres, Perrot (2007: 28) nos alerta sobre a importância dos "escritos femininos", como diários, cartas e autobiografias, para que possamos "ouvir suas vozes diretamente" e romper o silêncio que se abate há muito sobre elas. No entanto, em suas reflexões, ela reconhece o "pudor feminino que se estende à memória", razão, entre outras, pela qual muitas mulheres selecionavam e destruíam os vestígios de seus escritos ou simplesmente recusavam a falar de si, ainda mais quando havia o risco de que atentassem contra a sua honra. Por outro lado, podemos dizer que esses papéis, quando conservados e organizados, pressupõem um ato de vontade e resistência em busca da afirmação do "eu", ainda mais por se tratar, no caso em questão, de uma memória feminina ligada à presença de uma mulher no espaço público, lugar por muito tempo reservado à ação dos grandes homens.

É neste sentido que podemos analisar a autobiografia de Maria Lenk. Num primeiro momento, a seleção e ordenação do seu relato nos informa sobre uma consciência de si tomada pelo desejo de celebrar o jubileu dos Jogos de 1932, marco do seu triunfo esportivo por ter sido a primeira mulher sul-americana a competir em Olimpíadas. Contudo, à medida que avançamos, podemos perceber nos interstícios do relato as zonas de sombra, "as reticências, a imensidão do não dito, (...) o peso do seu silêncio", segundo destaca Perrot (2007: 27), representados pelos (res)sentimentos, tensões e contradições esboçados na narrativa, que tantas vezes a levaram a se desvalorizar apesar do feito realizado. Para além de re- 
velar sua vontade de calar e silenciar sobre determinadas vivências em torno desse acontecimento chave, essas passagens devem ser analisadas como irrupções súbitas de uma memória recalcada, comunicada metaforicamente em função de uma autocensura que impediu Maria Lenk de falar explicitamente sobre as humilhações, as dificuldades e os preconceitos de gênero enfrentados para ingressar e permanecer no campo esportivo, ainda que se tratasse de um esporte aquático, em tese mais adequado às mulheres. Conforme afirma Portelli (1996: 128), "até mesmo as memórias individuais dividem-se internamente entre o desejo de silenciar e esquecer e a necessidade de se expressar". Dessa forma, podemos dizer que o título dado à autobiografia - Braçadas e abraços - expressa uma síntese positiva da sua trajetória esportiva, realizada através de um duplo movimento: aludir ao que era inconfessável, para se libertar dos traumas e ressentimentos do passado e, assim, promover o reencontro e a reconciliação consigo mesma no presente.

Notas

1. $\mathrm{O}$ artigo 54 do Decreto proibia às mulheres "a prática de desportos considerados incompatíveis com as condições da sua natureza, devendo para este efeito o Conselho Nacional de Desportos baixar as necessárias instruções às entidades desportivas do país". Posteriormente, em 1965, o CND baixou a Deliberação n ${ }^{\circ} 7$, onde se registrava "não ser permitida a prática de lutas de qualquer natureza, futebol, futebol de salão, futebol de praia, pólo aquático, rugby, halterofilismo e baseball". O fim das restrições só ocorreu em 1979.

2. Acerca do trabalho elaborativo da memória, ver Jelin (2001).

3. A respeito desta noção, ver Bourdieu (1996).

4. Acerca do uso da noção de geração como elemento periodizante, ver Sirinelli (1996: 131-137).
5. Conforme Michael Pollak

(1992), "os acontecimentos 'vividos por tabela', são aqueles experimentados pelo grupo ou pela coletividade à qual a pessoa se sente pertencer".

6. Utilizei aqui, de forma mais abrangente, o conceito de comunidade afetiva, formulado por Halbwachs (1990: 33-36).

7. Para maiores informações sobre este conceito, ver Oberti (2006: 49-50).

8. Sobre esta noção, ver Vianna, Lissovsky e Moraes de Sá (1986).

9. O arquivo de Maria Lenk, constituído basicamente por 23 volumes de recortes de jornais, organizados por assunto e em ordem cronológica, e por algumas fotografias e objetos, encontram-se disponíveis para consulta na Biblioteca de Pós-Graduação em Educação Física da UGF.

10. Sobre este conceito, ver Pollak (1989). 
11. Acerca desta noção, ver Gomes (1996).

12. Sobre os paradoxos e as ambiguidades que cercam os conceitos de igualdade e diferença de gênero, ver Scott (2005: 11-30).

13. Declarações causticantes de Maria Lenk, Fornal dos Sports, Rio de Janeiro, 20/09/1932, p. 1.

14. Na hora da prova estavam com fome! Por que os brasileiros não disputaram os 4x400 em L.A, Fornal dos Sports, Rio de Janeiro, 20/09/1932, p. 1.

Referências bibliográficas

ANSART, Pierre. 2004. História e memória dos ressentimentos. In: BRESCIANI, Stella; NAXARA, Márcia (orgs.). Memória e (res)sentimento: indagações sobre uma questão sensível. Campinas: Unicamp.

BOCCARDO, Ludmila Mourão. 1998. Representação social da mulher brasileira na atividade físico-desportiva: $d a$ segregação à democratização. Tese (Doutorado em Educação Física) - Rio de Janeiro, UGF.

BOURDIEU, Pierre. 1996. A ilusão biográfica. In: FERREIRA, Marieta de Moraes; AMADO, Janaína (orgs.). Usos e abusos da história oral. Rio de Janeiro: FGV.

CARDOSO, Mauricio. 2000. Os arquivos das olimpíadas. São Paulo: Panda Boooks.

GOMES, Ângela de Castro. 1996. A guardiã da memória. Acervo - Revista do Arquivo Nacional, Rio de Janeiro, vol. 9, n. $1 / 2$, jan/dez.
15. Tempo ao tempo, Fornal dos

Sports, Rio de Janeiro, 20/09/1932, coluna Críticas e sugestões, p. 2.

16. Uma situação dificílima, Fornal dos Sports, Rio de Janeiro, 21/09/1932, coluna Críticas e sugestões, p. 2.

17. Pandiá Pires, jornalista que acompanhou a delegação olímpica, presta declarações desassombradas. Fornal dos Sports, Rio de Janeiro, 22/09/1932, p. 1.

2004. Escrita de si, escrita da história: a título de prólogo. In: GOMES, Ângela de Castro (org.). Escrita de si, escrita da história. Rio de Janeiro: FGV.

HALBWACHS, Maurice. 1990. A memória coletiva. São Paulo: Vértice.

JELIN, Elizabeth. 2001. Los trabajos de la memória. Buenos Aires: Siglo Vinteuno de Argentina.

LENK, Maria. 1982. Braçadas e abraços. Rio de Janeiro: Grupo Atlântica Boavista.

NORA, Pierre. 1993. Entre memória e história: a problemática dos lugares. Projeto História, São Paulo, PUC, n. 10, dezembro.

OBERTI, Alejandra. 2006. Contarse a sí mismas. La dimensión biográfica en los relatos de mujeres que participaron en las organizaciones político-militares de los '70. In: CARNOVALE, Vera; LORENZ, Federico; PITTALUGA, Roberto. Historia, memória e fuentes orales. Buenos Aires: Cedinci. 
PEREIRA, Ligia Maria Leite. 2000. Algumas reflexões sobre histórias de vida, biografias e autobiografias. In: História Oral - Revista da Associação Brasileira de História Oral, n. 3.

PERROT, Michelle. 2005. As mulheres ou os silêncios da história. São Paulo: Edusc.

2007. Minha história das mulheres. São Paulo: Contexto.

POLLAK, Michael. 1989. Memória, esquecimento, silêncio. Estudos Históricos, Rio de Janeiro, vol. 2, n. 3 .

1992. Memória e identidade social. Estudos Históricos, Rio de Janeiro: FGV, vol. 5, n. 10.

PORTELLI, Alessandro. 1996. O massacre de Civitella Val di Chiana (Toscana, 29 de junho de 1944): mito e política, luto e senso comum. In: FERREIRA, Marieta de Moraes; AMADO, Janaína (orgs.). Usos e abusos da história oral. Rio de Janeiro: FGV.

SARLO, Beatriz. 2005. Tiempo pasado. Cultura de la memória y giro subjetivo.
Una discusión. Buenos Aires: Siglo

Veintiuno.

SCOTT, Joan W. 2005. O enigma da igualdade. Estudos Feministas, Florianópolis, vol. 13, n. 1.

SCHPUN, Mônica Raisa. 1999. Beleza em jogo: cultura física e comportamento em São Paulo nos anos 20. São Paulo: Boitempo/Senac.

SIRINELLI, Jean-François. 1996. A geração. In: FERREIRA, Marieta de Moraes; AMADO, Janaína (orgs.). Usos e abusos da história oral. Rio de Janeiro: FGV. p. 131-137.

SOIHET, Racquel. 1997. História das mulheres. In: CARDOSO, Ciro Flamarion; VAINFAS, Ronaldo (orgs.). Domínios da história: ensaios de teoria e metodologia. Rio de Janeiro: Campus/Elsevier.

VIANNA, Aurélio; LISSOVSKY, Maurício; MORAES DE SÁ, Paulo Sérgio. 1986. A vontade de guardar: lógica da acumulação em arquivos privados. Arquivo e Administração, Rio de Janeiro, 10-14 (2), jul-dez.

\section{Resumo}

A partir do crescente interesse da história pela "escrita de si”, este artigo toma como base a autobiografia da nadadora Maria Lenk, com o objetivo de explorar as relações existentes entre memória, identidade, esquecimento e silêncio. Nessa perspectiva, o trabalho examina as estratégias de comunicação e representação empregadas na narrativa, bem como os "ditos" e os "não-ditos" do testemunho de Maria Lenk concernentes às recordações da sua participação nas Olimpíadas de 1932. Assim, algumas questões presentes nos relatos de histórias de vida são discutidas para compreender a lógica que envolve a construção desta ambígua memória feminina.

Palavras-chave: Maria Lenk, memória feminina, escrita autobiográfica, natação feminina brasileira, relações de gênero, consciência de gênero 


\section{Abstract}

Following the increasing interest of history in the "writing of self", this paper examines the swimmer Maria Lenk's autobiography, with the purpose of exploring relationships between memory, identity, forgetfulness and silence. To do so, it observes the communication and representation strategies used in the narrative, as well as what is "said" and "not-said" in Maria Lenk's testimony concerned to her participation in the Olympic Games. Some questions present in life story records are discussed in order to understand the logic that involves the building of this ambiguous feminine memory.

Key words: Maria Lenk, feminine memory, autobiographical writing, Brazilian feminine swimming, gender relations, gender conscience

\section{Résumé}

En face de l'intérêt croissant de l'histoire à "l'écriture de soi", cet article examine l'autobiographie de la nageuse Maria Lenk, dans le but d'exploiter les rapports entre la mémoire, l'identité, l'oubli et le silence. Dans cette perspective, le travail examine les stratégies de communication et de représentation employées dans le récit, aussi bien que les "dits" et "non-dits" du témoignage de Maria Lenk concernant sa participation aux Jeux Olympiques de 1932. Quelques questions présentes dans les témoignages d'histoire de vie sont discutées pour comprendre la logique qui domine la construction de cette mémoire féminine ambiguë.

Mots-clés: Maria Lenk, mémoire féminine, récit autobiographique, natation féminine brésilienne, relations de genre, conscience de genre 